\title{
Determination of Pesticide Residues in Tomato using Dispersive Solid-Phase Extraction and Gas Chromatography/Ion Trap Mass Spectrometry
}

\author{
Graziela C. R. Moura Andrade, ${ }^{*, a}$ Rosana M. O. Freguglia, ${ }^{a}$ Regina P. Z. Furlani, ${ }^{b}$ \\ Nádia H. Torres ${ }^{a}$ and Valdemar L. Tornisielo ${ }^{a}$
}

\author{
${ }^{a}$ Centro de Energia Nuclear na Agricultura (CENA), Universidade de São Paulo, \\ Av. Centenário, 303, 13400-970 Piracicaba-SP, Brazil
}

${ }^{b}$ Centro de Química de Alimentos e Nutrição Aplicada, Instituto de Tecnologia de Alimentos (ITAL), Av. Brasil, 2880, 13070-178 Campinas-SP, Brazil

\begin{abstract}
A cultura do tomate é frequentemente afetada por pragas, doenças e estresses abióticos, resultando em menor produtividade e perda de qualidade dos frutos. O uso intensivo de pesticidas em tomates sem utilização das boas práticas agrícolas tem causado grande preocupação quanto à provável contaminação do produto final. O método QuEChERS foi utilizado para a determinação de seis pesticidas (buprofezina, carbofurano, $\alpha$-endosulfan, $\beta$-endosulfan, sulfato de endosulfan e monocrotofós) em amostras de tomate coletadas em supermercados. O método envolveu a extração líquido-líquido com acetonitrila, adição de $\mathrm{MgSO} 4$ e $\mathrm{NaCl}$ seguida de extração em fase sólida dispersiva com PSA (amina primária secundária) e as análises foram realizadas com cromatografia gasosa/espectrometria de massa ion trap. O estudo de recuperação para os pesticidas variou de 71 a $111 \%$ e o desvio padrão relativo foi inferior a $15 \%$. Não foram detectados resíduos de pesticidas (> LOD) nas trinta e três amostras de tomate analisadas.
\end{abstract}

Tomato crop is frequently damaged by diseases, pests and abiotic stresses, resulting in lower yielding and loss of fruit quality. The intensive use of pesticides in tomatoes without observation of good agriculture practices and regulations has caused great concern with a probable final product contamination. The QuEChERS method of sample preparation was used for the determination of six pesticides (buprofezin, carbofuran, endosulfan- $\alpha$, endosulfan- $\beta$, endosulfan sulfate and monocrotophos) in thirty three tomato samples collected from local market retailers. The method involved extraction with acetonitrile, liquid-liquid partition with addition of $\mathrm{MgSO}_{4}$ and $\mathrm{NaCl}$ followed by dispersive solid phase extraction using primary secondary amine sorbent and the analyses were carried out with a gas chromatography/mass spectrometry equipment by ion trap. Recovery studies for different pesticides ranged from 71 to $111 \%$ and the relative standard deviation (RSD) was below 15\%. No pesticide residue was detected (> LOD) among the thirty three tomato samples analysed.

Keywords: QuEChERS, gas chromatography, pesticides, tomato

\section{Introduction}

Tomato (Lycopersicon esculentum Mill) fruit is worldwide one of the most important vegetable components of the human diet and it is consumed in natura, cooked or processed. Besides the basic nutritional properties, tomatoes contain bioactive compounds with antioxidant properties such as ascorbic acid, vitamin E, carotenoids (lycopene), flavonoids and phenolic acids that benefit human health. Nevertheless, tomato plants

*e-mail: grazielacrm@yahoo.com.br are susceptible to several pests and diseases that have been controlled with pesticides in different plant stadium in order to avoid significant yield losses. ${ }^{1,2}$

According to recent FAO information, the ten greatest tomato producer countries in 2007 were: China, United States, Turkey, India, Egypt, Italy, Iran, Spain, Brazil and Mexico. These countries are responsible for more than $73 \%$ of the world's tomato production, ${ }^{3}$ which doubled during the last 20 years.

The crop expansion is mainly attributed to the demand increase, or else, consumption increase. Between 1983 and 
2003, the world's average tomato consumption increased from $11 \mathrm{~kg}$ to $16 \mathrm{~kg}$ per capita per year, what means a $45.5 \%$ increase, according to data from Food and Agriculture Organization of the United Nations. ${ }^{4}$

The tomato production is favored by an adequate climate in several regions and during the whole year in Brazil. But, greater incidence of weeds, pests and diseases occur during the summer season, requiring large use of pesticides.

The correct use of pesticides provides the benefit of high food availability to the people. However, serious negative aspects might rise up from the indiscriminate use of such compounds in agriculture that might end up as the soil, water and crop product contamination.

Due to the pesticide toxicity character, several countries have established maximum residue limits (MRL) for the presence of pesticide residues in crop products. The MRL is established independently in each country as pesticide registrations and is determinate through the result of toxicological and agronomic studies. These values may vary depending on the existing environmental conditions in the country, differing pest pressures, differing pesticide use patterns and good agricultural practices. ${ }^{5}$

The list of permitted compounds in Brazil and establishment of residue limits for different crops are controlled by the national health surveillance agency (Agência Nacional de Vigilância Sanitária - ANVISA). In 2001, ANVISA started the Program of Food Residue Analysis with the objective of evaluating the pesticide residue levels in crop products for a better food security.

In Brazil, 141 active compounds are registered and permitted for application in tomato crops, in individual or combined formulations, totalizing 265 pesticide commercial brands. ${ }^{6}$ However, according to reported data, Brazil is still engaged, in some regions, with the problem of non-permitted compound use in tomatoes and the pesticide presence above the MRL. ${ }^{6}$ Nevertheless, the analysis of residues in samples considered above the MRL (using different validated methods for analysis of pesticide residue in tomatoes applied to real samples) showed relatively low residue values, meaning that, there is apparently an adequate use of pesticides in tomato crop in the studied regions, according to good agriculture practices., ${ }^{2,-9}$ Besides, a relatively low number of samples above the MRL were found in studies of real samples collected in local markets. ${ }^{10,11}$

In 2003, Anastassiades, Lehotay, Štajnbaher, \& Schenck introduced a sample preparation method named QuEChERS (quick, easy, cheap, effective, rugged and safe) involving pesticide dispersive solid phase extraction (dSPE), with primary secondary amine (PSA) sorbent. Compared to other procedures, the QuEChERS method is very fast and cheap.
This procedure has been worldwide used for studies on pesticide residue analysis in several matrices. ${ }^{12-17}$ In studies with tomato samples, satisfactory results were found for a wide range of pesticides analyzed. ${ }^{18-20}$

Some studies were performed comparing the QuEChERS method with other extraction techniques, ${ }^{21}$ including the determination of 12 organophosphorus and carbamates insecticides in honey samples by liquid chromatography-ion trap-mass spectrometry. ${ }^{22}$ Four different approaches were studied for the extraction step: QuEChERS, solid-phase extraction (SPE), pressurized liquid extraction (PLE) and solid-phase microextraction (SPME). The comparison showed that all of them recover all the selected pesticides with a good repeatability. Nevertheless, QuEChERS method presented the highest recoveries (mean recovery $91.67 \%$ ) followed by the SPE (mean recovery $90.25 \%$ ) and the PLE (mean recovery 90.25\%) whereas the SPME showed the lowest recovery (mean recovery of $49.75 \%$ ). The QuEChERS method was the most adapted method with around 58\% of recoveries higher than $90 \%$. Due to sufficient analytical performance and low cost QuEChERS method presents an attractive approach for routine applications.

Recently microextraction methods have been employed for pesticide analysis which usually requires both smaller sample size and organic solvent volumes when compared with the conventional methods. The main advantages of these procedures are the high degree of enrichment for the analytes in complex matrices, which enable limits of detection ${ }^{23,24}$ down to the levels required by the regulatory bodies to the analysis of pesticide residues in water and food. On other hand, despite their high-throughput, requires long extraction times, which is perhaps the major disadvantage of the technique and its automation seems to be very difficult and has not yet been achieved, thus new developments in this area are required. ${ }^{25}$

Other extraction techniques meant for pesticide analyses also have been employed for environmental and food matrices, including the supercritical fluid extraction (SFE), ${ }^{26}$ solid-phase extraction (SPE), ${ }^{27,28}$ and matrix solid phase dispersion (MSPD), ${ }^{29-32}$ but these techniques are more costly than the QuEChERS and require more skilled technicians.

Therefore, the objective of this study was to use the QuEChERS sample extraction method for the quantitative determination of pesticide residues in tomato samples, considering the possible matrix effects. The pesticides analyzed were buprofezin and carbofuran, largely used in Brazilian tomato crops to control pests and diseases, and also, endosulfan- $\alpha$, endosulfan- $\beta$, endosulfan sulfate and monocrotophos, which are non-permitted pesticides 
detected in samples analyzed by the monitoring program coordinated by ANVISA.

\section{Experimental}

\section{Standards and reagents}

Pesticide standards (buprofezin, carbofuran, monocrotophos, endosulfan-alpha, endosulfan-beta and endosulfan-sulphate) were purchased either from AccuStandard (New Haven, USA) or from Riedel-de-Haën (Seelze) with a minimum of $99 \%$ purity.

Stock solutions of individual standards $\left(10 \mathrm{mg} \mathrm{mL}^{-1}\right)$ were prepared in toluene, considering standard purity, and stored in dark flasks at $-20{ }^{\circ} \mathrm{C}$. The calibration standard solutions were prepared in toluene containing the six pesticides in concentrations ranging from 0.250 to $4.00 \mu \mathrm{g} \mathrm{mL}^{-1}$. Standard solutions prepared in acetonitrile were used for spiking tomatoes samples at $0.0625,0.250$ and $1.00 \mathrm{mg} \mathrm{kg}^{-1}$ levels.

Toluene and acetonitrile of HPLC or spectra grade were obtained from Tedia, and formic acid from JT Baker. High purity and anhydrous $\mathrm{MgSO}_{4}$ was purchased from SigmaAldrich, and $\mathrm{NaCl}$ from Mallinckrodt. Primary secondary amine (PSA) sorbent (40 $\mu \mathrm{m}$ particle size) was obtained from $\operatorname{Varian}^{\circledR}$.

\section{Samples}

Samples of tomatoes $(1 \mathrm{~kg})$ were monthly collected from different retailers in the City of Piracicaba, State of São Paulo, Brazil. Sampling was carried out during the period between August 2007 and October 2008. A total of 33 samples were analyzed in duplicate for the presence of six pesticides. The analytical method was validated using pesticide-free organically produced tomatoes.

\section{Analytical instrumentation and conditions}

The gas chromatographic analysis was performed on a Finnigan MAT GCQ gas chromatography-ion trap mass spectrometer (Thermo, USA). A fused silica capillary column, 5\%-phenyl-methylpolysiloxane as stationary phase ( $30 \mathrm{~m} \times 0.25 \mathrm{~mm}$ i.d.) and $0.25 \mu \mathrm{m}$ film thickness (Quadrex, Woodbridge, U.S.A) was used with helium as carrier gas at a constant flow $\left(1 \mathrm{~mL} \mathrm{~min}{ }^{-1}\right)$.

The system was equipped with split-splitless injection inlet and $2 \mu \mathrm{L}$ aliquot of sample or standard was injected in splitless mode at $250^{\circ} \mathrm{C}$. The GC oven was operated with the following temperature program: initial temperature $100{ }^{\circ} \mathrm{C}$ held for $3 \mathrm{~min}$, ramped at $25^{\circ} \mathrm{C} \mathrm{min}^{-1}$ to $175^{\circ} \mathrm{C}$ not held, followed by a ramp of $8{ }^{\circ} \mathrm{C} \mathrm{min}^{-1}$ to $290^{\circ} \mathrm{C}$ and held for $5 \mathrm{~min}$. The total run time was $25 \mathrm{~min}$ and XCalibur 1.2 chromatography data system software was used for instrument control and data analysis.

Transfer line temperature was set at $275^{\circ} \mathrm{C}$ and the source temperature at $175{ }^{\circ} \mathrm{C}$. The mass spectrometer was operated in selected ion monitoring mode (SIM) with an electron impact (EI) ionization whith an ionizing energy of $70 \mathrm{eV}$.

Analysis was performed in the selected ion monitoring mode (SIM) according to the parameters shown in Table 1, based on the use of one target and two qualifier ions and according to the retention times. Target and qualifier ions were determined by injection of individual pesticide standards under the same chromatographic conditions in full-scan mode.

Table 1. Retention time and SIM detection parameters of studied pesticides

\begin{tabular}{lccc}
\hline Pesticides & $\begin{array}{c}\text { Retention } \\
\text { time / min }\end{array}$ & $\begin{array}{c}\text { Ions monitored } \\
\text { in SIM }^{\mathrm{a}}\end{array}$ & $\begin{array}{c}\mathrm{M} / \\
\left(\mathrm{g} \mathrm{mol}^{-1}\right)\end{array}$ \\
\hline Monocrotophos & 10.93 & $\mathbf{1 2 7}, 67,97$ & 223 \\
Carbofuran & 11.62 & $\mathbf{1 6 4}, 149,122$ & 221 \\
Endosulfan-alpha & 16.29 & $\mathbf{1 9 5}, 241,277$ & 407 \\
Buprofezin & 16.78 & $\mathbf{1 7 5}, 172,105$ & 305 \\
Endosulfan-beta & 17.95 & $\mathbf{1 9 5}, 241,339$ & 407 \\
Endosulfan-sulfate & 18.85 & $\mathbf{2 7 2}, 229,387$ & 423 \\
\hline
\end{tabular}

aTarget ions are printed in bold.

Spiked blank samples were used as standards to counteract possible matrix effects.

\section{Sample preparation}

The tomato samples were rinsed in water and ground to complete liquefying and homogenized for 5 min using a domestic blender and stored in glass flasks and kept frozen at $-20{ }^{\circ} \mathrm{C}$ until analysis.

The samples were prepared according to the QuEChERS method, ${ }^{33}$ as follows: $10 \mathrm{~g}$ aliquot sample was transferred into a teflon centrifuge tube, and $10 \mathrm{~mL}$ acetonitrile were added and the solution was homogenized using an Ultra-Turrax homogenizer at $12.000 \mathrm{rpm}$ for $2 \mathrm{~min}$; then, $4 \mathrm{~g}$ anhydrous $\mathrm{MgSO}_{4}$ and $1 \mathrm{~g} \mathrm{NaCl}$ were added and the solution was shaken again for $1 \mathrm{~min}$; the tube was centrifuged for $5 \mathrm{~min}$ at $5.000 \mathrm{rpm} ; 6 \mathrm{~mL}$ aliquot of the upper layer were transferred to a teflon centrifuge tube containing $150 \mathrm{mg}$ PSA and $900 \mathrm{mg}$ anhydrous $\mathrm{MgSO}_{4}$. The extract ( $\mathrm{pH} 8$ ) was vigorously shaken for $1 \mathrm{~min}$ and then centrifuged for $5 \mathrm{~min}$ at $5.000 \mathrm{rpm}$.

The upper layer was filtered through Teflon filter $0.45 \mu \mathrm{m}$ and $2 \mathrm{~mL}$ of extract were transferred into a glass flask and $20 \mu \mathrm{L}$ of $5 \%$ formic acid in acetonitrile 
solution were added ( $\mathrm{pH} 5-5.5$, where most acid and base labile pesticides are sufficiently stabilized); the extract was then evaporated to dryness(about $30 \mathrm{~min}$ ). Care was taken to remove the tube immediately to prevent overdrying; following, $500 \mu \mathrm{L}$ of toluene and $0.107 \mathrm{~g}$ of anhydrous $\mathrm{MgSO} 4$ were added to the dry extract, which was centrifuged for $5 \mathrm{~min}$ at $5.000 \mathrm{rpm}$ and transferred to GC vial for GC analysis. The samples were analyzed as soon as prepared or stored in a freezer to avoid any adverse affect on the analytes evaluated.

\section{Method validation}

The parameters used to validate the method were linearity, matrix effect, precision and accuracy, sensibility (limits of detection and quantification) and repeatability. All the analyses were carried out using the pesticide-free organically produced tomatoes.

Linearity was studied by constructing analytical curves using standard solutions in toluene and in the matrix extract for comparison purposes. The range was from 0.250 to $4.00 \mathrm{ng} \mu \mathrm{L}^{-1}$ and three injections were made at each of the six concentration levels.

Precision and accuracy data were obtained with recovery tests carried out by spiking samples of organic tomatoes with pesticide standards at levels of $0.0625,0.250$ and $1.00 \mathrm{mg} \mathrm{kg}^{-1}$. The spiked samples as well as the unspiked controls were analyzed in three replicates. The method repeatability was evaluated through the relative standard deviation (RSD\%) associated to pesticide measurements performed during the recovery procedures.

The limits of detection (LOD) and quantification (LOQ) were calculated as 3.3 and 10 times respectively, the ratio between the standard deviation of the response $(\sigma)$ and the slope of the calibration curve (S) and was estimated based on the specific calibration curve in the range of LOD. The estimate of $\sigma$ expressed as the standard deviation of y-intercepts of regression lines was used as the standard deviation. ${ }^{34}$

\section{Results and Discussion}

\section{Validation study}

The mean recoveries for spiked sample and RSD ranged from 71 to $111 \%$ and 8 to $15 \%$, respectively (Table 2). In the lowest spike level $\left(0.0625 \mathrm{mg} \mathrm{kg}^{-1}\right)$ six pesticides were recovered in the range of 77 to $107 \%$ as recommended by SANCO Guidelines which prove mean recovery values within the range $70-120 \% .{ }^{35}$ Figure 1 shows a chromatogram

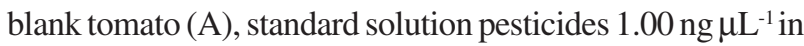
toluene (B) and spiked tomato $1.00 \mathrm{ng} \mu \mathrm{L}^{-1}(\mathrm{C})$ whose peaks have their characteristic ions presented in Table 1.

All pesticides showed linearity in the concentration range of 0.250 to $4.00 \mathrm{mg} \mathrm{L}^{-1}$, with determination coefficients $\mathrm{r}^{2}$ higher than 0.990 (Table 2). Relative standard deviations (RSD\%) of the three replicate injections ranged from 4.00 to $15.0 \%$ meaning good precision. LOQs of the method were in the range of $0.0127-0.0501 \mathrm{mg} \mathrm{kg}^{-1}$, which are below the MRLs established for these compounds by ANVISA.

\section{Matrix effect}

A significant better linearity was observed for all pesticides $\left(r^{2}>0.990\right)$ when analyzed in the matrix extract, evidencing a positive matrix influence on parameters of linear interval and $\mathrm{r}^{2}$, making more stable the chromatographic system responses and providing better analytical sensibility and precision (Figure 2).
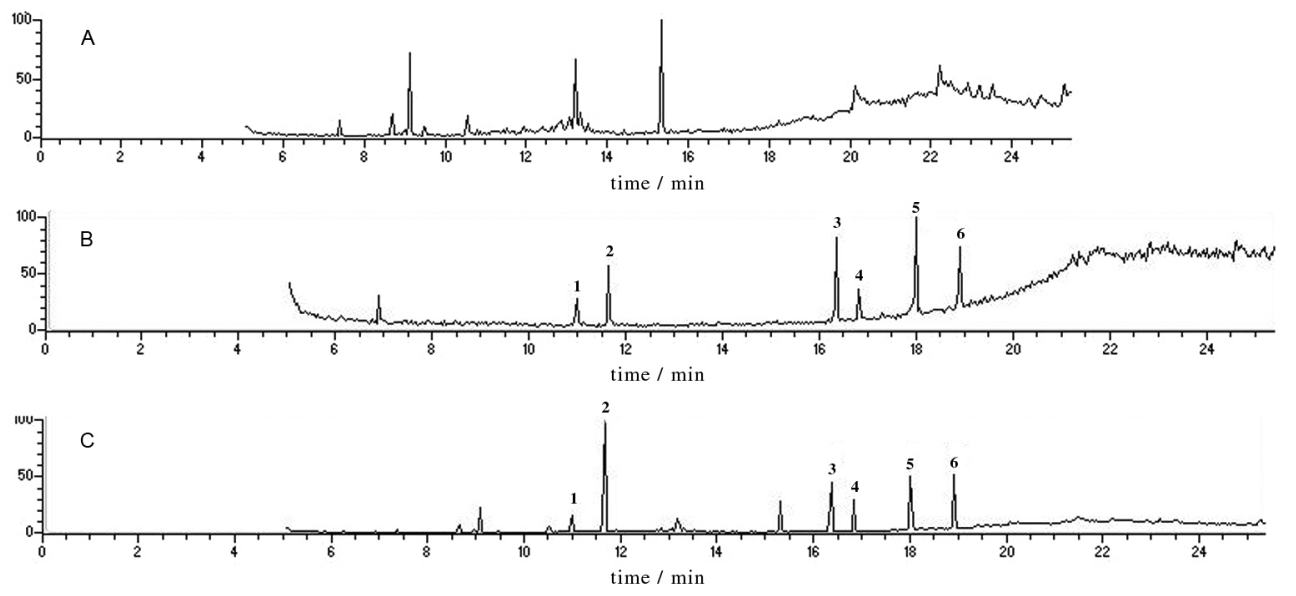

Figure 1. Chromatograms of (A) blank tomato sample, (B) standard solution in toluene $\left(1.00 \mathrm{ng} \mu \mathrm{L}^{-1}\right)$ and (C) spiked tomato sample $\left(1.00 \mathrm{ng} \mu \mathrm{L}^{-1}\right)$. Chromatographic conditions are described in the Experimental section. 1: Monocrotophos, 2: Carbofuran, 3: Endosulfan-alpha, 4: Buprofezin, 5: Endosulfanbeta and 6: Endosulfan-sulfate. 
Table 2. Calibration data (equation, determination coefficient $\left.\mathrm{r}^{2}\right)$, mean percent recovery $\left(\mathrm{R}_{\mathrm{m}}\right.$ ), relative standard deviation (RSD), limit of quantification (LOQ) of pesticides in tomato samples and maximum residue limit (MRL)

\begin{tabular}{|c|c|c|c|c|c|c|c|c|}
\hline Pesticide & $\begin{array}{l}\text { Calibration Curve } \\
\text { Equations }\left(\mathrm{r}^{2}\right)\end{array}$ & $\begin{array}{c}\text { Spiked level / } \\
\left(\mathrm{mg} \mathrm{kg}^{-1}\right)\end{array}$ & $\mathrm{R}^{*}$ & $\begin{array}{c}\mathrm{RSD} / \\
(\%)\end{array}$ & $\begin{array}{l}\mathrm{R}_{\mathrm{m}} / \\
(\%)\end{array}$ & $\mathrm{RSD}_{\mathrm{m}}$ & $\begin{array}{c}\mathrm{LOQ} / \\
\left(\mathrm{mg} \mathrm{Kg}^{-1}\right) \\
\end{array}$ & $\begin{array}{c}\text { MRL / } \\
\left(\mathrm{mg} \mathrm{Kg}^{-1}\right) \\
\end{array}$ \\
\hline \multirow[t]{3}{*}{ Buprofezin } & \multirow{3}{*}{$\begin{array}{c}y=153443 x-33397 \\
(0.999)\end{array}$} & 0.0625 & 77 & 8 & \multirow[t]{3}{*}{71} & \multirow[t]{3}{*}{9} & \multirow[t]{3}{*}{0.0501} & $0.500^{\mathrm{a}}$ \\
\hline & & 0.250 & 72 & 8 & & & & $1.00^{\mathrm{b}}$ \\
\hline & & 1.00 & 63 & 12 & & & & \\
\hline \multirow[t]{3}{*}{ Carbofuran } & \multirow{3}{*}{$\begin{array}{c}\mathrm{y}=439148 \mathrm{x}-34238 \\
(0.999)\end{array}$} & 0.0625 & 107 & 11 & \multirow[t]{3}{*}{111} & \multirow[t]{3}{*}{8} & \multirow[t]{3}{*}{0.0264} & $0.100^{\mathrm{a}}$ \\
\hline & & 0.250 & 101 & 6 & & & & $-^{c}$ \\
\hline & & 1.00 & 125 & 8 & & & & \\
\hline \multirow[t]{3}{*}{ Endosulfan alpha } & \multirow{3}{*}{$\begin{array}{c}y=202705 x-426 \\
(0.999)\end{array}$} & 0.0625 & 94 & 6 & \multirow[t]{3}{*}{83} & \multirow[t]{3}{*}{9} & \multirow[t]{3}{*}{0.0127} & $0.500^{\mathrm{b}}$ \\
\hline & & 0.250 & 80 & 8 & & & & $-{ }^{* * c_{c}}$ \\
\hline & & 1.00 & 75 & 13 & & & & \\
\hline \multirow[t]{3}{*}{ Endosulfan beta } & \multirow{3}{*}{$\begin{array}{c}y=211004 x-6259 \\
(0.999)\end{array}$} & 0.0625 & 83 & 9 & \multirow[t]{3}{*}{75} & \multirow[t]{3}{*}{11} & \multirow[t]{3}{*}{0.0362} & \multirow[t]{3}{*}{-} \\
\hline & & 0.250 & 70 & 15 & & & & \\
\hline & & 1.00 & 72 & 9 & & & & \\
\hline \multirow[t]{3}{*}{ Endosulfan sulfate } & \multirow{3}{*}{$\begin{array}{c}y=247295 x-234 \\
(0.999)\end{array}$} & 0.0625 & 99 & 7 & \multirow[t]{3}{*}{79} & \multirow[t]{3}{*}{11} & \multirow[t]{3}{*}{0.0244} & \multirow[t]{3}{*}{-} \\
\hline & & 0.250 & 72 & 14 & & & & \\
\hline & & 1.00 & 66 & 12 & & & & \\
\hline \multirow[t]{3}{*}{ Monocrotophos } & \multirow{3}{*}{$y=142194 x-29623$} & 0.0625 & 103 & 17 & \multirow[t]{3}{*}{80} & \multirow[t]{3}{*}{15} & \multirow[t]{3}{*}{0.0229} & \multirow[t]{3}{*}{$-^{\mathrm{c}}$} \\
\hline & & 0.250 & 75 & 13 & & & & \\
\hline & & 1.00 & 62 & 14 & & & & \\
\hline
\end{tabular}

${ }^{*} \mathrm{n}=3 ; \mathrm{R}=$ Recovery; ${ }^{*}$ Total endosulfan (sum of alpha, beta and sulfate). Source: ${ }^{\mathrm{a} A N V I S A}{ }^{36}$; ${ }^{\mathrm{b}}$ CODEX ALIMENTARIUS; ${ }^{37}$ No MRLs established or prior MRLs revoked in Codex and/or ANVISA.

\section{Monocrotophos}

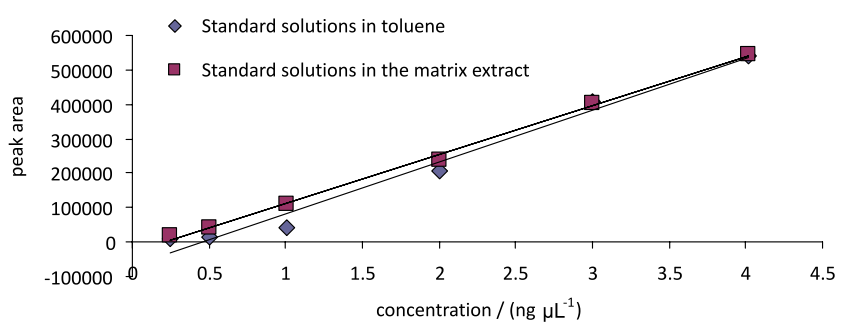

\section{Carbofuran}

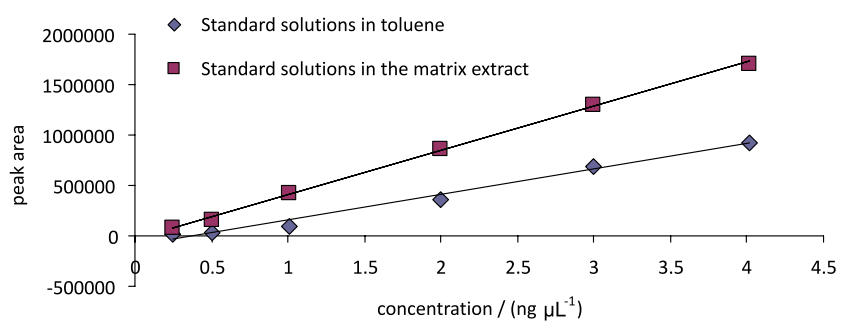

\section{Endosulfan- $\beta$}

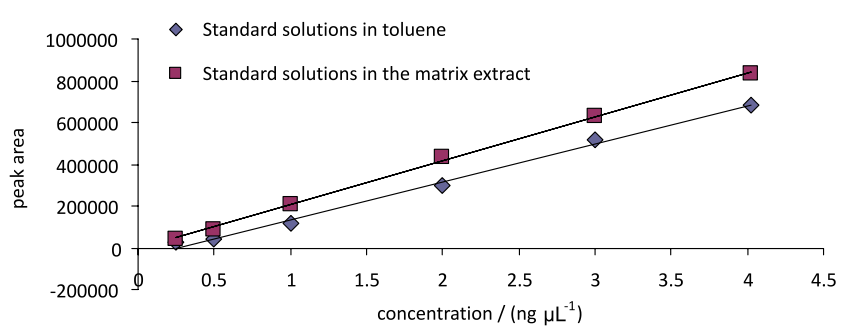

Buprofezin

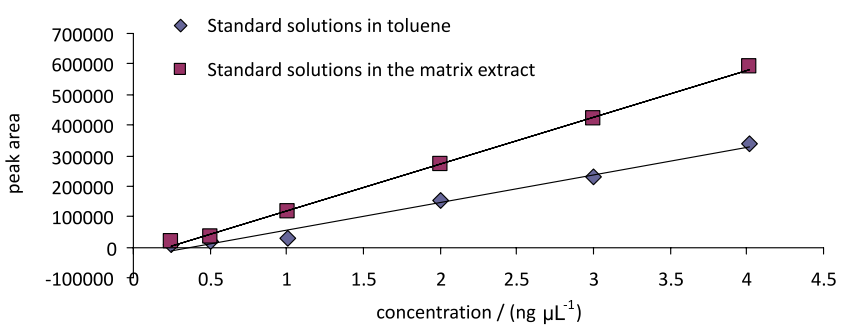

Endosulfan- $\alpha$

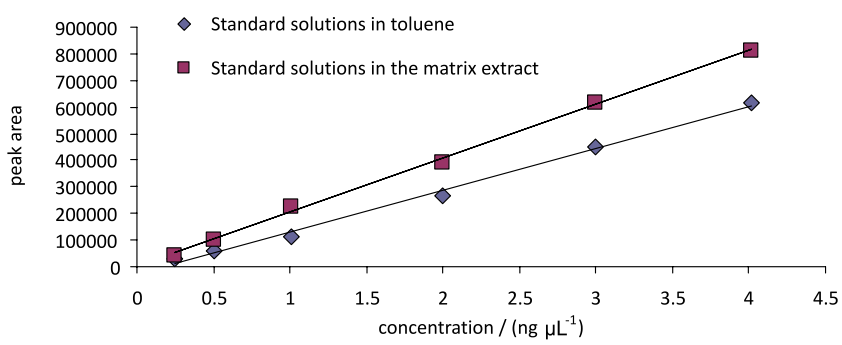

Endosulfan-sulfate

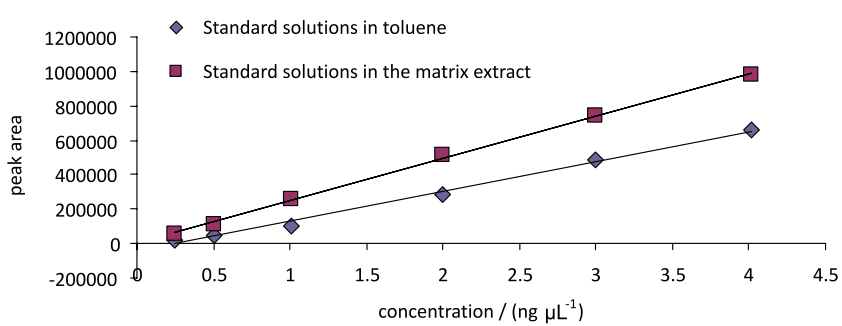

Figure 2. Comparison between the slopes of standard curves prepared in toluene and tomato matrix. 
The relationship between the curve slopes obtained in solvent and matrix provide information about the matrix effect. Another way of evaluating the matrix effect is the use of $F$ test and Student $t$ test. In this study, a $20 \%$ increase or decrease on the slope was considered matrix effect (Table 3 ).

Table 3. Matrix effects estimated by the angular coefficient variation of the curves in solvent and matrix $(\mathrm{ME} \%)$, and by the $F$ and $t$ tests $(p<0.05)$

\begin{tabular}{|c|c|c|c|}
\hline Pesticide & $\begin{array}{l}\mathrm{ME} / \\
(\%)\end{array}$ & Statistics & $\begin{array}{l}\text { Conclusion from the } \\
\text { two evaluations }\end{array}$ \\
\hline Buprofezin & 71 & $\begin{array}{c}F \text { test: } F_{\mathrm{cal}}>F_{\mathrm{tab}} \\
t \text { test: } t_{\mathrm{cal}}>t_{\mathrm{tab}}\end{array}$ & $\begin{array}{l}\text { Significant } \\
\text { matrix effect }\end{array}$ \\
\hline Carbofuran & 74 & $\begin{array}{c}F \text { test: } F_{\mathrm{cal}}>F_{\mathrm{tab}} \\
t \text { test: } t_{\mathrm{cal}}>\mathrm{t}_{\mathrm{tab}}\end{array}$ & $\begin{array}{l}\text { Significant } \\
\text { matrix effect }\end{array}$ \\
\hline Endosulfan-alpha & 29 & $\begin{aligned} F \text { test: } F_{\mathrm{cal}} & >F_{\mathrm{tab}} \\
T \text { test: } t_{\mathrm{cal}} & >t_{\mathrm{tab}}\end{aligned}$ & $\begin{array}{l}\text { Significant } \\
\text { matrix effect }\end{array}$ \\
\hline Endosulfan-beta & 16 & $\begin{aligned} F \text { test: } F_{\mathrm{cal}}>F_{\mathrm{tab}} \\
T \text { test: } t_{\mathrm{cal}}>t_{\mathrm{tab}}\end{aligned}$ & $\begin{array}{l}\text { Significant } \\
\text { matrix effect }\end{array}$ \\
\hline Endosulfan-sulfate & 42 & $\begin{aligned} F \text { test: } F_{\mathrm{cal}} & >F_{\mathrm{tab}} \\
T \text { test: } t_{\mathrm{cal}} & >t_{\mathrm{tab}}\end{aligned}$ & $\begin{array}{l}\text { Significant } \\
\text { matrix effect }\end{array}$ \\
\hline Monocrotophos & -5 & $\begin{array}{c}F \text { test: } F_{\mathrm{cal}}<F_{\mathrm{tab}} \\
T \text { test: } t_{\mathrm{cal}}<t_{\mathrm{tab}}\end{array}$ & $\begin{array}{l}\text { Non-significant } \\
\text { matrix effect }\end{array}$ \\
\hline
\end{tabular}

According to the literature, several compounds might be extracted together with the pesticides from the matrix, introducing spectral interferences. The interpretation of a positive or negative matrix effect over the method selectivity and the magnitude of such effect will depend on the matrix/pesticide interaction. ${ }^{38}$ The matrix effect is compound-dependent, ${ }^{39}$ probable due to the different components co-extracted with pesticides from the matrix.

Nowadays, the best procedure to minimize this influence on the pesticide quantification is to correct the matrix effect by means of matrix-matched calibrations. ${ }^{13,40,41}$

\section{Determination in tomato samples}

The thirty three tomato samples collected from local market retailers, prepared and analyzed for the pesticide determinations as described above, presented no detectable residues of pesticides, evidencing that the results were within the actual regulation for tomatoes.

The physicochemical properties (Table 4) of pesticides, as well as the frequency of use, mode of application, biotic and abiotic characteristics of the environment and weather conditions can determine their destination in the environment. With the adsorption coefficient $\left(\mathrm{K}_{\mathrm{oc}}\right)$ it is possible to predict the tendency of the pesticide to be adsorbed onto organic matter in soil (buprofezin). Chemicals with low $\mathrm{K}_{\text {ow }}$ values (monocrotophos, carbofuran) may be considered relatively hydrophilic; they tend to have high water solubilities, small soil/sediment adsorption coefficients, and small bioconcentration factors for aquatic life. The moderately high Henry's law constant combined with low water solubility means that endosulfan have a strong tendency to partition from water to air meaning that may evaporate readily from formulations applied.

The results obtained in this study with the evaluation and monitoring of different pesticide classes such as the organochlorine pesticides (endosulfan- $\alpha$ and $-\beta$, endosulfan sulfate), organophosphorus pesticides (monocrotophos), thiadiazine (buprofezin) and carbamates (carbofuran) evidenced that the proposed method of sample preparation and pesticide residue analysis involves fast, easy and sensible procedures. Besides, it has the advantage of employing lower amount of organic solvents, reducing the contamination risks for the lab-technicians and environment.

\section{Conclusions}

The QuEChERS method used in this study showed to be a simple, dynamic and effective procedure that can be run in any laboratory, since it eliminates slow and difficult steps used in other methods of pesticide extraction.

The method validation results were satisfactory, since the recovery data and relative standard deviation (RSD\%) values indicated good method accuracy and precision

Table 4. Physicochemical properties of the pesticides under study

\begin{tabular}{|c|c|c|c|c|}
\hline Pesticide & $\begin{array}{l}\text { Solubility in water } \\
\left(20^{\circ} \mathrm{C}\right) /\left(\mathrm{mg} \mathrm{L}^{-1}\right)^{\mathrm{a}}\end{array}$ & $\begin{array}{c}\log \mathrm{pK}_{\mathrm{ow}} \\
\left(\mathrm{pH} 7,20^{\circ} \mathrm{C}\right)^{\mathrm{a}}\end{array}$ & $\mathrm{K}_{\mathrm{oc}} /\left(\mathrm{mL} \mathrm{g}^{-1}\right)^{\mathrm{a}}$ & $\begin{array}{c}\text { Henry's Constant } \\
\left(25^{\circ} \mathrm{C}\right) /\left(\mathrm{Pa} \mathrm{m}^{3} \mathrm{~mol}^{-1}\right)^{\mathrm{a}}\end{array}$ \\
\hline Buprofezin & 0.46 & 4.93 & 2722 & $2.8 \times 10^{-02}$ \\
\hline Carbofuran & 322 & 1.8 & 23.3 & $5.0 \times 10^{-05}$ \\
\hline Endosulfan-alpha & 0.32 & 4.74 & 11500 & 1.48 \\
\hline Endosulfan-beta & n.d. & n.d. & n.d. & n.d. \\
\hline Endosulfan-sulfate & n.d. & n.d. & n.d. & n.d. \\
\hline Monocrotophos & 818000 & -0.22 & 19 & n.d. \\
\hline
\end{tabular}

${ }^{\mathrm{a}}$ IUPAC $;{ }^{42}$ n.d.: not determined. 
$\left(r^{2}>0.990\right)$ for the pesticides buprofezin, carbofuran, endosulfan- $\alpha$, endosulfan- $\beta$, endosulfan-sulfate and monocrotophos, when evaluated in tomato matrix.

Several and varied interactions may occur among sample-pesticide-chromatographic system, which turn difficult to define a behavior tendency for the matrix effect. Therefore, it is recommended the quantification based on analytical standards prepared in matrix blank extracts to compensate the matrix effects and get more accurate results.

All analyzed samples showed low levels of pesticide residues, below the limits of detection (LOD) for the compounds buprofezin, carbofuran, endosulfan- $\alpha$, endosulfan- $\beta$, endosulfan-sulfate and monocrotophos, indicating that the tomato producers have followed the actual legislation and adopted good agricultural practices in the studied region.

This study evidenced that the QuEChERS method with dispersive solid phase extraction (dSPE) may be used in multiresidue routine analysis of tomatoes, with low LOD and LOQ values and good analytical precision.

\section{Acknowledgments}

The authors are grateful to FAPESP, a research foundation of the State of São Paulo, for financial support.

\section{References}

1. Menezes Filho, A.; Navickiene, S.; Dorea, H. S.; J. Braz. Chem. Soc. 2006, 17, 874.

2. Gambacorta, G.; Faccia, M.; Lamacchia, C.; Di Luccia, A.; La Notte, E.; Food Control 2005, 16, 629.

3. http://faostat.fao.org/site/567/DesktopDefault. aspx?PageID=567\#ancor, accessed in April 2011.

4. http://faostat.fao.org/site/609/DesktopDefault. aspx?PageID=609\#ancor\%20per\%20capita/, accessed in April 2011.

5. D’Mello, J. P. F.; Food Safety: Contaminants and Toxins, Cabi Publishing: New York, 2003.

6. http://portal.anvisa.gov.br/ accessed in April 2011. (Search: analise+residuo+alimento) - Programa de Análise de Resíduos de Agrotóxicos em Alimentos (PARA).

7. Fenoll, J.; Hellín, P.; Martínez, C. M.; Miguel, M.; Flores, P.; Food Chem. 2007, 105, 711.

8. Frenich, A. G.; Vidal, J. L. M.; López, T. L.; Aguado, S. C.; Salvador, I. M.; J. Chromatogr., A 2004, 1048, 199.

9. Martínez Vidal, J. L.; Arrebola, F. J.; Mateu-Sánchez, M.; J. Chromatogr., A 2002, 959, 203.

10. Rissato, S. R.; Galhiane, M. S.; de Souza, A. G.; Apon, B. M.; J. Braz. Chem. Soc. 2005, 16, 1038.
11. Gobo, A. B.; Kurz, M. H. S.; Pizzutti, I. R.; Adaime, M. B.; Zanella, R.; J. Braz. Chem. Soc. 2004, 15, 945.

12. Lehotay, S. J.; Mastovska, K.; Lightfield, A. R.; J. AOAC Int. 2005, 88,615 .

13. Lehotay, S. J.; Mastovska, K.; Yun, S. J.; J AOAC Int. 2005. 88 , 630.

14. Hernández-Borges, J.; Cabrera, J. C.; Rodríguez-Delgado, M. A.; Hernández-Suárez, E. M.; Saúco, V. G.; Food Chem. 2009, $113,313$.

15. Fernandez-Alvarez, M.; Llompart, M.; Lamas, J. P.; Lores, M.; Garcia-Jares, C.; Cela, R.; Dagnac, T.; J. Chromatogr., A 2009, 1216, 2832.

16. Cunha, S. C.; Fernandes, J. O.; Alves, A.; Oliveira, M. B. P. P.; J. Chromatogr., A 2009, 1216, 119.

17. Furlani, R. P. Z.; Marcilio, K. M.; Leme, F. M.; Tfouni, S. A. V.; Food Chem. 2011, 126, 1283.

18. Lesueur, C.; Knittl, P.; Gartner, M.; Mentler, A.; Fuerhacker, M.; Food Control 2008, 19, 906.

19. Kmellár, B.; Fodor, P.; Pareja, L.; Ferrer, C.; Martínez-Uroz, M. A.; Valverde, A.; Fernandez-Alba, A. R.; J. Chromatogr., A 2008, 1215, 37.

20. Wang, S.; Xu, Y.; Pan, C.; Jiang, S.; Liu, F.; Anal. Bioanal. Chem. 2007, 387, 673

21. Díez, C.; Traag, W. A.; Zommer, P.; Marinero, P.; Atienza, J.; J. Chromatogr., A 2006, 1131, 11.

22. Blasco, C.; Vazquez-Roig, P.; Onghena, M.; Masia, A.; Picó, Y.; J. Chromatogr., A 2011, 1218, 4892.

23. Romero-González, R.; Pastor-Montoro, E.; Martínez-Vidal, J. L.; Garrido-Frenich, A.; Rapid Commun. Mass Spectrom. 2006, 20, 2701.

24. Lüthje, K.; Hyötyläinen, T.; Rautiainen-Rämä, M.; Riekkola, M. L.; Analyst, 2005, 130, 52.

25. Cunha, S. C.; Fernandes, J. O.; Oliveira, M. B. P. P.; Current Trends in Liquid-Liquid Microextraction for Analysis of Pesticide Residues in Food and Water, InTech: Rijeka, 2011.

26. Rissato, S. R.; Galhiane, M. S.; Knoll, F. R. N.; Apon, B. M.; J. Chromatogr., A 2004, 1048, 153.

27. Albero, B.; Sánchez-Brunete, C.; Tadeo, J. L.; J. Agric. Food Chem. 2004, 52, 5828.

28. Sharif, Z.; Man, Y. B. C.; Hamid, N. S. A.; Keat, C. C.; J. Chromatogr., A 2006, 1127, 254.

29. Albero, B.; Sánchez-Brunete, C.; Donoso, A.; Tadeo, J. L.; J. Chromatogr., A 2004, 1043, 127.

30. Barker, S. A.; J. Chromatogr., A 2000, 880, 63.

31. Bogialli, S.; Di Corcia, A.; J. Biochem. Biophys. Methods 2007, $70,163$.

32. Hu, Y. Y.; Zheng, P.; He, Y. Z.; Sheng, G. P.; J. Chromatogr., A 2005, 1098, 188.

33. Anastassiades, M.; Lehotay, S. J.; Štajnbaher, D.; Schenck, F. J.; J. AOAC Int. 2003, 86, 412. 
34. http://www.ich.org/products/guidelines/quality/article/qualityguidelines.html (Analytical Validation Q2, Q2(R1)), accessed in April 2011.

35. http://ec.europa.eu/food/plant/protection/resources/ qualcontrol_en.pdf, accessed in April 2011.

36. http://portal.anvisa.gov.br/ accessed in April 2011. (Search: monografias+agrotoxicos) - Monografias de agrotóxicos autorizadas e excluídas.

37. http://www.codexalimentarius.net/pestres/data/pesticides/index. html, accessed in April 2011.

38. Schenck, F. J.; Lehotay, S. J.; J. Chromatogr., A 2000, 868, 51.
39. Hajslova, J.; Holadova, K.; Kocourek, V.; Poustka, J.; Godula, M.; Cuhra, P.; Kempny, M.; J. Chromatogr., A 1998, 800, 283.

40. Zrostlikova, J.; Hajslova, J.; Godula, M.; Mastovska, K.; J. Chromatogr., A 2001, 937, 73.

41. Hajslova, J.; Zrostlýkova, J.; J. Chromatogr., A 2003, 1000, 181.

42. http://sitem.herts.ac.uk/aeru/iupac/index.htm, accessed in April 2011.

Submitted: November 4, 2010

Published online: June 14, 2011

FAPESP has sponsored the publication of this article. 